Agro-Science Journal of Tropical Agriculture, Food, Environment and Extension Volume 19 Number 4 (October 2020) pp. 24 - 29

ISSN1119-7455

\title{
NUTRITIONAL DIVERSITY IN ACCESSIONS OF AFRICAN WALNUT (Plukenetia conophora L.) SOURCED FROM SOUTHWESTERN NIGERIA AS INFLUENCED BY COLLECTION CENTER AND PROCESSING
}

\author{
${ }^{1}$ Olajide K., ${ }^{* 2}$ Baiyeri K.P. and ${ }^{2}$ Ndubuaku U.M. \\ ${ }^{1}$ Kogi State College of Education (Technical), Kabba, Kogi State, Nigeria \\ ${ }^{2}$ Department of Crop Science, University of Nigeria, Nsukka, Enugu State, Nigeria \\ *Corresponding author's email: paul.baiyeri@unn.edu.ng
}

\begin{abstract}
Nut collection expeditions of Plukenetia conophora L. were made to 10 locations in southwestern Nigeria. Seeds extracted were cooked or not and were assayed for phytochemical and mineral contents. Data obtained were statistically analyzed. Omuwo-Oke accession had highest phenol and tannin whereas Ijan had highest phytate; alkaloids and glycosides were higher in Ara accession than others. Accession obtained from Aramoko gave highest iron concentration while the lowest was in Ogotun accession. The concentrations of $\mathrm{K}, \mathrm{Mg}$ and Na were higher in Ogotun accession while the lowest was found in Alafe, Agbado and Aba-Oyo, respectively. Alafe accession had highest concentration of phosphorus but lower concentration was obtained in Ogotun. Zinc was highest in collection from Aramoko while Abgado accession had the lowest. Phenol, phytate, alkaloids and glycosides were higher in boiled nuts than fresh nuts but tannin was higher in fresh nuts. $\mathrm{K}, \mathrm{Mg}, \mathrm{Zn}$ and Na were higher in fresh nuts than boiled nuts. Higher concentration of Fe and $\mathrm{P}$ were recorded in boiled nuts. Genotype $x$ traits biplot analysis revealed that cooked nuts from Agbado, Alafe, and Aramoko had higher values for glycosides. Alkaloid was more pronounced in fresh nut from Ara. Fresh nuts from Aba-Oyo and Agbado gave higher values for phytate. Tannin was highest in fresh nuts from Omuo-Oke and boiled nuts from Igbara-Odo while phenol was higher in boiled nut from Omuo-Oke. Biplot analysis for minerals revealed higher concentration of $\mathrm{Zn}, \mathrm{NFE}, \mathrm{Na}$ and $\mathrm{P}$ in boiled nuts from Aramoko, Omuo-Oke, Igbara-Odo, Ogotun and Ijan. Mg was highest in fresh nuts from Ara and Igbara-Odo. Tannin and alkaloids had negative significant relationship $\left(r=-0.581^{*}\right)$ but the relationship between glycosides and alkaloids was positive and significant $\left(r=0.520^{*}\right)$. Zn had significant relationships with $\mathrm{Mg}$ and $\mathrm{P}\left(r=0.590^{*}\right.$ and $-0.551^{*}$, respectively). Similarly, $\mathrm{Na}$ had positive relationships with $\mathrm{K}$ and $\mathrm{Mg}(r=0.599 *$ and $0.491 *$, respectively). $M g$ and $K$ had an r-value of 0.502*. Inter-correlative responses between the phytochemicals and minerals revealed that only glycosides had significant relationships with $\mathrm{K}, \mathrm{Mg}$ and $\mathrm{Zn}$ (which were negative) as well as with P (which was positive). Data obtained suggested sufficient genetic diversity in nuts of Plukenetia sourced from southwestern Nigeria, indicating posibility for selection. Besides, cooking had signifcant (in some cases, positive) effect on the phytochemicals and minerals assayed.
\end{abstract}

Key words: African walnut, accessions, phytochemical, minerals, processing

\section{INTRODUCTION}

African walnut (Plukenetia conophora L.) is a perennial climbing species belonging to the family Euphorbiaceae (Amaeze et al., 2011). P. conophora is commonly referred to as African walnut because of its West African origin. It is known as 'Ekporo' by Efik and Ibibios of Cross River and Akwa Ibom, as 'Ukpa' in Igbo, 'Awusa' or 'Asala' in Yoruba, 'Okwe' in Edo and 'Gwandi bairi' in Hausa (Akpuaka and Nwankwor, 2000). Plukenetia conophora is better appreciated for its seeds, which are extensively consumed by people inhabiting the Southern region of Nigeria where the species is common (Akpuaka and Nwankwor, 2000). The plant starts flowering between one and half to two years after planting. In Nigeria, $P$. conophora plants flower between November and early January and fruit between January and September with peak production in July. The immature fruits are usually green in colour but turn dark brown as they mature (Oluwole and Okusanya, 1993). The fruit is a fourwinged ribbed capsule, containing sub-globule seeds with a thin brown and yellow kernel. The fruit ( $7 \mathrm{~cm}$ across) are light green to brown when ripe while the seeds are round dark brown at maturity. Each seed is about $2.5 \mathrm{~cm}$ in diameter.

The importance of Plukenetia as an indigenous fruit climber is enormous as it is a multi-purpose crop. In West Africa, especially in Nigeria and Sierra Leone the fruits provide income to the rural people thereby improving their economy. $P$. conophora, like many plants in Africa and other

Please cite as: Olajide K., Baiyeri K.P. and Ndubuaku U.M. (2020). Nutritional diversity in accessions of African walnut (Plukenetia conophora L.) sourced from southwestern Nigeria as influenced by collection center and processing. Agro-Science, 19 (4), 24-29. DOI: https://dx.doi.org/10.4314/as.v19i4.5 
parts of the world has been proven to have nutritive, medicinal, agricultural and industrial values over the years (Baiyeri et al., 2019). Conophor plants are cultivated principally for the nuts, which are usually cooked and consumed as snacks (Enujiugha and Ayodele, 2003). Food materials are usually processed in order to improve its palatability and reduce toxicity, and as a means of preservation (Kanu et al., 2015). Plukenetia seeds are generally consumed after several processing techniques. General method of processing walnut prior to consumption involves prolonged cooking of the seeds by boiling and roasting with or without the shell. Nwaoguikpe et al. (2012) reported that wet and smashed samples of walnut seeds contain (in percent) 1.90 phenol, 0.51 tannin and 0.41 alkaloids. Enujiugha (2003) reported that walnut seeds contain mineral concentration in the raw nut $465.95 \mathrm{mg} / 100 \mathrm{~g}$ phosphorus, $57.37 \mathrm{mg} / 100 \mathrm{~g}$ magnesium, $1.55 \mathrm{mg} / 100 \mathrm{~g}$ iron and $6.84 \mathrm{mg} / 100 \mathrm{~g}$ zinc. The importance of these mineral elements in human health has already been proven. They are implicated in several body functions such as enzymatic reactions, energy production, transmission of nerve impulses, and multiple biological reactions (Steinberg et al., 2003).

Studies have reported the effect of processing on the nutritional value, anti-nutritional and antioxidant properties of Plukenetia seeds in southeastern Nigeria (Udeonyia et al., 2013; 2014; Agbo and Baiyeri, 2019). However, there are limited reports on the effect of accession and processing on phytochemical and mineral properties of walnut grown in southwestern Nigeria. Therefore, the objective of this study was to assay for minerals and phytochemical contents of accessions of Plukenetia from southwestern Nigeria and also to explore the possible effect of cooking on these nutritional traits.

\section{MATERIALS AND METHODS}

Expedition for seed collection was carried out in July 2018 from some locations in southwestern Nigeria. African walnut capsules were sourced from nine locations in five local government areas (LGA) of Ekiti State and one location in a LGA in Kogi State. The location(s) within each LGA are Alafe and Aramoko in Ekiti West LGA, Ara and Aba-oyo in Ikole LGA, Agbado and Ijan Gbonyin in LGA, Igbara Odo and Ogotun in Ekiti South West LGA and Omuwo-Oke in Ekiti East LGA and Oranre in Yagba East LGA. Seeds were extracted from the capsules and separated according to location of collection. The seeds were thoroughly washed; samples for laboratory analyses were fresh nuts and nuts boiled in water for $60 \mathrm{~min}$. (samples were steam-cooked). Replicated samples were assayed to determine the contents of phytochemicals and minerals following international standards in accordance with AOAC (2005). Zinc, magnesium, and iron were determined using Model 210 VGP of the Buck Scientific AAS series with air-acetylene gas mixture as oxidant. Sodium and potassium were determined using flame photometer (Corning Clinical Flame Photometer Model 410 with air-butane gas mixture as oxidant). Phosphorus was assayed for using colorimetric method. Distillation and titrimetric procedure was followed to determine the quantity of alkaloids in the samples. Phytate was quantified following MaGA (1983) method. At a wavelength of $510 \mathrm{~nm}$ absorbance of samples were read using Spectrophotometer (Labomed spectronic 20D) to determine the concentration of glycosides and phenols. Spectronic 21D spectrophotometer at a wavelength of $760 \mathrm{~nm}$ was employed to determine the concentration of tannin in the samples. Data collected were subjected to analysis of variance (ANOVA) using GENSTAT Discovery edition 3 Release 7.22 DE (GENSTAT, 2008). Significant differences between means were detected by Fisher's least significant difference (F-LSD) at 5\% level of probability. Following Yan and Kang (2003) method, genotype $\mathrm{x}$ traits biplot analysis was used to model patterns of variation in the second order interaction involving accession, processing and traits. Also, relationships within and between minerals and phytochemicals were established through correlation analysis.

\section{RESULTS}

The effect of accession on phytochemicals composition of nuts of Plukenetia is presented in Table 1 . The quantity of phenol, phytate, and tannin were statistically similar among the accessions evaluated, however, alkaloids and glycosides varied significantly $(p<0.05)$. Accession obtained from Omuwo-Oke had the highest phenol and tannin content relative to other accessions. Ijan accession had the highest phytate while the least was observed in Igbara-Odo accession. Alkaloids and glycosides were significantly $(p<0.05)$ higher in Ara accession than others.

Table 2 shows that the concentration of iron, magnesium, phosphorus and sodium were significantly $(p<0.05)$ influenced by accessions while potassium and zinc were statistically similar among the accessions. Nuts from Aramoko had the highest iron concentration while the lowest was Ogotun accession. Nuts obtained from Ogotun had the highest potassium, magnesium and sodium concentration but the nuts from Alafe, Agbado and Aba-Oyo contained the least of these irons, respectively. Phosphorus concentration was highest in accession from Alafe but lowest in Ogotun accession. Aramoko accession had the highest zinc concentration while Abgado accession had the least. 
Table 1: Main effect of accession on some phytochemical contents (\%) of 10 accessions of Plukenetia conophora seeds

\begin{tabular}{lccccc}
\hline Accession & Phenols & Phytate & Tanin & Alkaloid & Glycoside \\
\hline Aba-Oyo & 0.256 & 0.0155 & 0.0803 & 0.5601 & 0.1549 \\
Agbado & 0.247 & 0.0150 & 0.0860 & 0.5495 & 0.1527 \\
Alafe & 0.249 & 0.0156 & 0.0848 & 0.5440 & 0.1480 \\
Ara & 0.259 & 0.0157 & 0.0816 & 0.5621 & 0.1588 \\
Aramoko & 0.239 & 0.0143 & 0.0820 & 0.5457 & 0.1434 \\
Igbara-Odo & 0.237 & 0.0139 & 0.0774 & 0.5299 & 0.1341 \\
Ijan & 0.240 & 0.0248 & 0.0853 & 0.5379 & 0.1395 \\
Ogotun & 0.247 & 0.0149 & 0.0741 & 0.5460 & 0.1442 \\
Omuo-Oke & 0.546 & 0.0154 & 0.0866 & 0.5539 & 0.1559 \\
Oranre & 0.248 & 0.0152 & 0.0794 & 0.5539 & 0.1550 \\
LSD $_{(0.05)}$ & $\mathrm{ns}$ & $\mathrm{ns}$ & $\mathrm{ns}$ & 0.01599 & 0.01236 \\
\hline
\end{tabular}

Table 2: Main effect of accession on mineral contents $(\mathrm{mg} / \mathrm{kg})$ of Plukenetia conophora seeds

\begin{tabular}{|c|c|c|c|c|c|c|}
\hline Accession & $\mathrm{Fe}$ & $\mathrm{K}$ & $\mathrm{Mg}$ & $\mathrm{P}$ & $\mathrm{Zn}$ & $\mathrm{Na}$ \\
\hline Aba-Оyo & 20.32 & 10294 & 4531 & 180.1 & 61.11 & 680.0 \\
\hline Agbado & 25.55 & 9989 & 4522 & 178.1 & 56.38 & 671.9 \\
\hline Alafe & 22.05 & 9609 & 4653 & 237.3 & 58.77 & 697.4 \\
\hline Ara & 20.00 & 11194 & 4982 & 221.5 & 61.00 & 717.2 \\
\hline Aramoko & 29.74 & 11331 & 4993 & 214.5 & 69.03 & 747.8 \\
\hline Igbara-Odo & 17.89 & 10988 & 5052 & 155.5 & 60.52 & 752.6 \\
\hline Ijan & 20.88 & 10103 & 4582 & 210.3 & 57.11 & 673.9 \\
\hline Ogotun & 13.08 & 11521 & 5252 & 159.0 & 58.21 & 849.1 \\
\hline Omuo-Oke & 23.85 & 10038 & 5135 & 208.4 & 59.61 & 724.2 \\
\hline Oranre & 13.72 & 10938 & 4786 & 197.0 & 56.95 & 723.0 \\
\hline $\operatorname{LSD}_{(0.05)}$ & 6.887 & $\mathrm{~ns}$ & 438.2 & 28.15 & ns & 50.92 \\
\hline
\end{tabular}

Fe - Iron, K - Potassium, Mg - magnesium, P - Phosphorus, Zn - Zinc, Na - Sodium

Variability in the concentration of phytochemicals and minerals in Plukenetia nuts due to processing was in most cases significant (Tables 3 and 4). Phenol, phytate, alkaloids and glycosides were higher in boiled nuts than fresh nuts, conversely, tannin was found to be higher in fresh nuts (Table 3). Processing significantly ( $p<0.05$ ) influenced iron, magnesium, phosphorus and zinc contents whereas potassium and sodium concentration were nonsignificant. Fresh nuts contained higher amount of potassium, magnesium, zinc and sodium than the boiled nuts. However, higher concentrations of iron and phosphorus were recorded in boiled nuts.

The biplot in Figure 1 revealed combined effects of accessions and processing on the concentration of phytochemical in the nuts. Boiled nuts from Agbado, Alafe, and Aramoko (2b, 3b and 5b) had higher value for glycosides. Alkaloid was evidently higher in fresh nut from Ara (4f). For phytate, fresh nuts from Aba-Oyo and Agbado (1f and 2f) gave higher values. Tannin was observed to be highest in fresh nuts from Omuo-Oke (9f) and boiled nuts from Igbara-Odo (6b). Boiled nut from Omuo-Oke (9b) was outstanding in phenols.

Figure 3 similarly shows the combined effects of accession and processing on mineral contents of Plukenetia nuts. The biplot revealed that zinc, nitrogen free extract, sodium and phosphorus, were more prominent in boiled nuts from Aramoko, Omuo-Oke, Igbara-Odo, Ogotun and Ijan (5b,9b, $6 \mathrm{~b}, 8 \mathrm{~b}, 10 \mathrm{~b})$. Also, fresh nuts from Agbado and Ijan ( $2 \mathrm{f}$ and $7 \mathrm{f}$ ) had higher quantity of phosphorus. But in respect to magnesium, fresh nuts from Ara and Igbara-Odo (4f and 6f) had the highest. Also, fresh nuts from Aramoko, Ogotun and Oranre, (5f, $8 \mathrm{f}$ and 10f) gave higher value for potasium.

Traits correlation matrices shown in Tables 5, 6 and 7 revealed some significant correlative responses. Tannin and alkaloids had negative significant relationship ( $r=-0.581 *$ ) but the relationship between glycosides and alkaloids was positive and significant $\left(r=0.520^{*}\right)$ (Table 5). Zn had significant relationships with $\mathrm{Mg}$ and $\mathrm{P}\left(r=0.590^{*}\right.$ and $r=-0.551^{*}$, respectively). Similarly, Na had positive relationships with $\mathrm{K}$ and $\mathrm{Mg}\left(r=0.599^{* *}\right.$ and $r=0.491^{*}$, respectively). $\mathrm{Mg}$ and $\mathrm{K}$ had an $\mathrm{r}$-value of $0.502^{*}$ (Table 6). Inter-correlative (Table 7) responses between the phytochemicals and minerals revealed that only glycosides had significant correlation with $\mathrm{K}, \mathrm{Mg}$, and $\mathrm{Zn}$ (which were negative) and positive relationship only with $\mathrm{P}$. Phytate had negative nonsignificant relationship with $\mathrm{K}$ and $\mathrm{Mg}$, but positive non-significant relationship with $\mathrm{P}$. Phenol and $\mathrm{Zn}$ had an inverse non-significant reltionship (Table 7).

Table 3: Main effect of processing on some phytochemical contents (\%) of 10 accessions of Plukenetia conophora seeds

\begin{tabular}{lccccc}
\hline Processing & Phenol & Phytate & Tanin & Alkaloid \\
\hline Fresh & 0.243 & 0.0142 & 0.0851 & 0.5419 & 0.1396 \\
Boiled & 0.31 & 0.0179 & 0.0784 & 0.5547 & 0.1577 \\
LSD $_{(0.05)}$ & ns & ns & 0.00406 & 0.00715 & 0.00553 \\
\hline
\end{tabular}

\begin{tabular}{|c|c|c|c|c|c|c|}
\hline Processing & $\mathrm{Fe}$ & $\mathrm{K}$ & $\mathrm{Mg}$ & $\mathrm{P}$ & $\mathrm{Zn}$ & $\mathrm{Na}$ \\
\hline Fresh & 16.82 & 10781.0 & 5076.0 & 162.7 & 65.20 & 729.2 \\
\hline Boiled & 24.59 & 10420.0 & 4621.0 & 229.7 & 54.54 & 718.2 \\
\hline $\operatorname{LSD}_{(0.05)}$ & 3.08 & ns & 196.0 & 12.59 & 3.907 & ns \\
\hline
\end{tabular}

Fe - Iron, K - Potassium, Mg - magnesium, P - Phosphorus, Zn - Zinc, Na - Sodium 


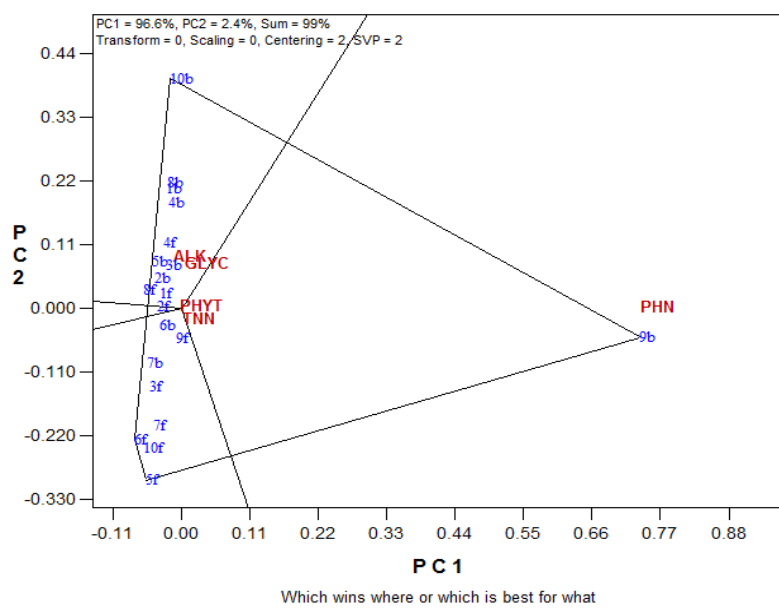

Figure 1: GGE biplot showing combined effects of accessions and processing on phytochemical traits of Plukenetia conophora seeds

Alk - alkaloids, Glyc - glycoside, Phyt - phytate,

Tnn - tannin, Phn - phenol

1f - Aba-Oyo (fresh), 2f - Agbado (fresh), 3f - Alafe (fresh), 4f - Ara (fresh), 5f - Aramoko (fresh), of - Igbara-Odo (fresh), $7 \mathrm{f}$ - Ijan (fresh), 8f - Ogotun (fresh), 9f - Omuo-Oke (fresh), $10 \mathrm{f}$ - Oranre (fresh)

1b - Aba-Oyo (boiled), 2b - Agbado (boiled), 3b - Alafe (boiled), $4 \mathrm{~b}$ - Ara (boiled), 5b - Aramoko (boiled), 6b - Igbara-Odo (boiled), 7b - Ijan (boiled), 8b - Ogotun (boiled), 9b - Omuo-Oke (boiled), $10 \mathrm{~b}$ - Oranre (boiled)

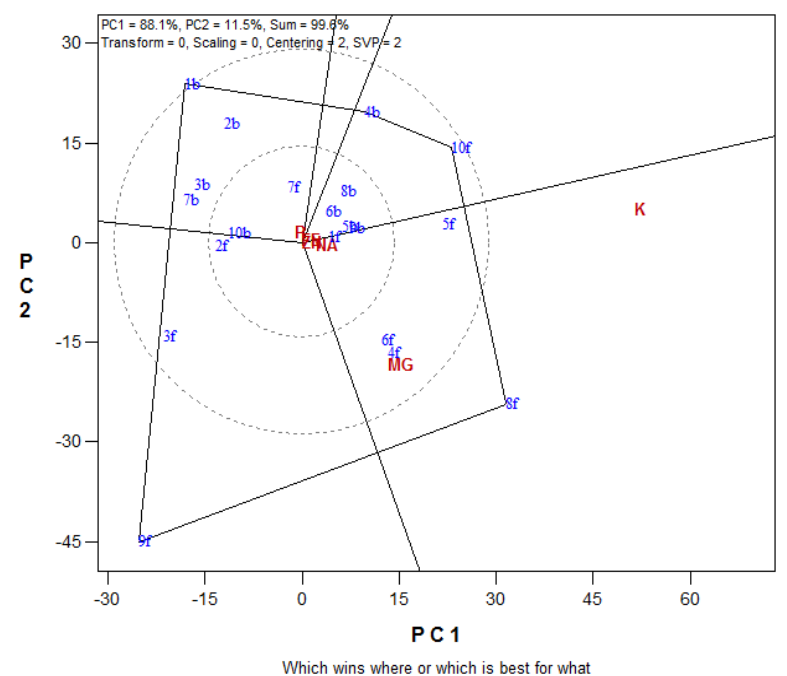

Figure 2: GGE biplot showing combined effects of accessions and processing on concentration of minerals in seeds of Plukenetia conophora

Fe - Iron, $\mathrm{K}$ - Potassium, Mg - Magnesium, P - Phosphorus, Zn - Zinc, Na - Sodium

1f - Aba-Oyo (fresh), 2f - Agbado (fresh), 3f - Alafe (fresh), 4f - Ara (fresh), 5f - Aramoko (fresh), 6f - Igbara-Odo (fresh), $7 \mathrm{f}$ - Ijan (fresh), 8f - Ogotun (fresh), 9f - Omuo-Oke (fresh), $10 \mathrm{f}$ - Oranre (fresh)

$1 \mathrm{~b}$ - Aba-Oyo (boiled), 2b - Agbado (boiled), 3b - Alafe (boiled), 4b - Ara (boiled), 5b - Aramoko (boiled), 6b - Igbara-Odo (boiled), $7 \mathrm{~b}$ - Ijan (boiled), 8b - Ogotun (boiled), $9 \mathrm{~b}$ - Omuo-Oke (boiled), 10b - Oranre (boiled)
Table 5: Intra-correlation coefficients among phytochemicals of Plukenetia conophora seeds

\begin{tabular}{|c|c|c|c|c|c|}
\hline & Phenol & Phytate & Tanin & Alkaloid & Glycoside \\
\hline Phenol & - & -0.086 & 0.052 & -0.128 & 0.066 \\
\hline Phytate & & - & 0.006 & 0.039 & 0.170 \\
\hline Tanin & & & - & $-0.581 *$ & -0.305 \\
\hline Alkaloid & & & & - & $0.520 *$ \\
\hline Glycoside & & & & & - \\
\hline
\end{tabular}

*Significant at 5\% probability level

Table 6: Intra-correlation coefficients among minerals in Plukenetia conophora seeds

\begin{tabular}{|c|c|c|c|c|c|c|}
\hline & $\mathrm{Fe}$ & $\bar{K}$ & $\mathrm{Mg}$ & $P$ & $\mathrm{Zn}$ & $\mathrm{Na}$ \\
\hline $\mathrm{Fe}$ & - & -0.186 & -0.311 & 0.315 & 0.076 & -0.202 \\
\hline $\mathrm{K}$ & & 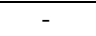 & $0.502 *$ & -0.337 & 0.195 & 0.599 *** \\
\hline $\mathrm{Mg}$ & & & - & $-0.596 * *$ & $0.590^{*}$ & $0.491^{*}$ \\
\hline $\mathrm{P}$ & & & & - & $-0.551 *$ & -0.355 \\
\hline $\mathrm{Zn}$ & & & & & - & 0.130 \\
\hline $\mathrm{Na}$ & & & & & & - \\
\hline
\end{tabular}

Table 7: Inter-correlation coefficients between minerals and phytochemicals of Plukenetiaconophora seeds

\begin{tabular}{llllll}
\hline & Phenol & Phytate & Tanin & Alkaloid & Glycoside \\
\hline $\mathrm{Fe}$ & 0.183 & 0.064 & 0.017 & -0.008 & 0.087 \\
$\mathrm{~K}$ & 0.062 & -0.407 & -0.216 & 0.024 & $-0.492^{*}$ \\
$\mathrm{Mg}$ & 0.012 & -0.340 & 0.130 & -0.106 & $-0.449^{*}$ \\
$\mathrm{P}$ & 0.315 & 0.378 & -0.250 & 0.150 & $0.579^{*}$ \\
$\mathrm{Zn}$ & -0.347 & -0.197 & 0.243 & 0.295 & $-0.475^{*}$ \\
$\mathrm{Na}$ & 0.019 & -0.265 & -0.344 & 0.015 & -0.305 \\
\hline
\end{tabular}

\section{DISCUSSION}

The total phenol, phytate, tannin, alkaloid and glycocide detected in this study were lower than those of Udedi et al. (2014) and Nwaoguikpe et al. (2012) in dried and powdered, wet and mashed nuts. The mineral content however, was outstanding. The mineral analysis of African walnut showed that the nut was rich in iron, potassium, magnesium, phosphorus, zinc and sodium. The result corresponded with the work of Enujiugha (2003) and Sibbeth (1994) that walnut is a good source of potassium and many other micronutrients, which implies that for human consumption, African walnuts could be recommended as a good source of minerals needed for body metabolism and proper functioning of cells.

Total phenol, phytate, alkaloid and glycoside were higher in the boiled nuts than fresh nut; increased value of tannin was evident in fresh nut but lower value in boiled nut. Generally, both fresh and boiled nuts were found to be high in all the mineral contents assayed for. Boiled nuts were higher in iron and phosphorus contents but the concentration of magnesium and zinc was higher in fresh nut; processing did not statistically influence potassium and sodium contents of the nuts. The lower values of potassium, magnesium, zinc and sodium in the boiled nuts might be attributed to loss of these minerals in water during cooking through diffusion process. The importance of these mineral elements in human health has been proven; they are implicated in several body functions such as enzymatic reactions, energy production, transmission of nerve impulses and multiple biological reactions (Steinberg et al., 2003). 
Boiling boosted the amount of iron in walnut and this indicated that, boiling for 60 minutes as was done in this study was suitable for the release of iron in walnut seeds. This result agrees with the report of Djikeng et al. (2017) that higher values of iron were obtained in boiled nuts than in the raw nuts (28.81 and $20.84 \mathrm{mg} / 100 \mathrm{~g}$, respectively). The amount of iron provided by walnut can help alleviate or prevent nutritional anemia associated with iron deficiency. Although the amounts of potassium and sodium decreased in values during boiling compared to fresh nut, their concentrations were higher than 625 and $26 \mathrm{mg} / 100 \mathrm{~g}$ reported by Ayoola et al. (2011) and Djikeng et al. (2017), respectively. The minerals in African walnut are beneficial to human health due to their direct relationship with hypertension in human. This may be the reason why the plant is used to prevent and control high blood pressure (James, 2000).

The decrease in the quantity of magnesium in boiled nut could be attributed to the loss of this mineral during processing through the diffusion process. The amount of magnesium obtained in this study was higher than $171.12 \mathrm{mg} / 100 \mathrm{~g}$ as previously reported by Ayoola et al. (2011) and Djikeng et al. (2017) in walnut.

The value for phosphorus in this study was higher in boiled nuts than in fresh nuts contrary to the report of Djikeng et al. (2017) who reported a decrease in phosphorus concentration (between 16.86 and $22.38 \mathrm{mg} / 100 \mathrm{~g}$ ) in all the cooked samples. The result obtained in this study was higher than $35 \mathrm{mg} / 100 \mathrm{~g}$ previously reported by Nwaoguikpe et al. (2012). Variability reported here could be associated with accession evaluated and the soil conditions the accession grew on. Earlier reports by Agbo and Baiyeri (2019) observed significant diversity in some proximate and mineral contents of five accessions studied, and their study also suggested the probable roles of genetic diversity and variability in soils the plants grew on.

The concentration of zinc was registered to be highest in fresh nuts than in boiled nuts. This result is not in conformity with the report of Ajewole et al. (2013) who reported an increased concentration of zinc in boiled nut than in raw nut, though in low concentrations, 10.60 and 5.60 $\mathrm{mg} / 100 \mathrm{~g}$, respectively.

\section{CONCLUSION}

The objective of this study was to evaluate the effect of accession and processing on nutritional content of walnut seeds. Phenol and tannin contents were highest in accession from Omuwo-Oke. Accession from Ijan had the highest phytate while Ara accession was higher in terms of alkaloids and glycosides. Iron concentration was higher in accession from Aramoko. Ogotun accession was found to be the best with respect to potassium, magnesium and sodium. Phosphorus was highest in Alafe accession. Highest zinc concentration was noticed in accession from Aramoko. It was found that boiling increase phenol, phytate, alkaloids and glycosides while tannin was highest in fresh nuts. Higher concentration of iron and phosphorus were recorded in boiled nuts than in fresh nuts. Potassium, magnesium, zinc and sodium were observed to be higher in fresh nuts than in boiled nuts.

\section{ACKNOWLEDGEMENT}

The first author acknowledges with thanks funding of this study, which is an aspect of his Ph.D. research funded by the Tertiary Education Trust Fund (TETFUND), Nigeria.

\section{REFERENCES}

Ajewole K., Abibu M.A. and Taleat A.A. (2013). Proximate analysis of the edible part of the African walnut (Juglans spiecie). Natural Products an Indian Journal, 9 (2), 51-54

Akpuaka M.U. and Nwankwor E. (2000). Extraction, analysis and utilization of a drying oil from Tetracarpidium conophorum (Nigerian walnut). Bioresource Technology, 73 (2), 195-196

Amaeze O.U., Ayoola G.A., Sofidiya M.O., et al. (2011). Evaluation of antioxidant activity of Tetracarpidium conophorum (Mull. Arg) Hutch \& Dalziel leaves. Oxidative Medicine \& Cellular Longevity, 2011, article ID 976701. DOI: 10.1155/2011/976701

AOAC (2005). Official Methods of Analysis of Association of Analytical Chemists International. $18^{\text {th }}$ edn., 2, 45. AOAC International Publications, Gaithersburg, MD

Ayoola P.B., Onawumi O.O. and Faboya O.O.P. (2011). Chemical evaluation and nutritive values of Tetracarpidium conophorum (Nigeria walnut) seeds. Journal of Pharmaceutical \& Biomedical Science, 11, 1-5

Agbo E.A. and Baiyeri K.P. (2019). Location influenced proximate and mineral composition of fresh nuts of five accessions of African walnut (Plukenetia conophora Muell Arg). Nigerian Journal of Crop Science, 6 (1), 30-33

Baiyeri K.P., Ugese F.D. and Nwobodo C.E. (2019). Diversity, food, nutrition and medicinal importance of some selected less-known African indigenous tropical plant species: advocacy for global research attention. $C A B$ International. (Online ISSN 1749-8848). DOI: 10.1079/PAVSNNR201914012

Djikeng T.F., Selle E., Morfor A.T., et al. (2017). Effect of boiling and roasting on lipid quality, proximate composition, and mineral content of walnut seeds (Tetracarpidium conophorum) produced and commercialized in Kumba, Southwest Region Cameroon. Food Science \& Nutrition, 6 (2), 417-423. DOI: $10.1002 / \mathrm{fsn} 3.570$

Enujiugha V.N. and Ayodele-Oni O. (2003). Evalution of nutrients and anti-nutrients in some lesser known under-utilized oilseeds. International Journal of Food Science \& Technology, 38, 525-528

Enujiugha V.N. (2003). Chemical and functional characteristics of conophor nut. Pakistan Journal of Nutrition, 2 (6), 335-338 
Genstat (2008). Genstat 7.22.0 Release 3 DE Discovery Edition, Lawes Agricultural Trust, Rothmanisted Experimental Station, UK

James N.R. (2000). Volatile components of green walnut husks. Journal of Agricultural \& Food Chemistry, 48, 2858-2861. https://doi.org/10.1021/jf000288b [PubMed]

Kanu A.M., Kalu J.E. and Okorie A.C. (2015). Nutritional and health values of African walnut (Tetracarpidium conophorum). International Journal of Scientific \& Technology Research, 4, 215-220

Maga J.A. (1983). Phytate: its chemistry, occurrence, food interactions, nutritional significance and method of analysis. Journal of Agricultural \& Food Chemistry, 30 (1), 1-9. https://doi.org/10.1021/jf0010ga001

Nwaoguikpe R.N., Ujowundu C.O. and Wesley B. (2012). Phytochemical and biochemical compositions of African walnut (Tetracarpidium conophorum). Journal of Pharmaceutical \& Biomedical Sciences, 20, 1-5

Oluwole S.O. and Okusanya O.T. (1993). Dormancy and seed germination in the African walnut (Tetracarpidium conophorum Mull. Arg.). Journal Scientific Research Development, 1, 9-14
Sibbet S.G. (1994). Edible tree nuts, walnuts. Encyclopedia of Agricultural Science, 2, 9-16

Steinberg F.M., Bearden M.M. and Keen C.L. (2003). Cocoa and chocolate flavonoids: Implications for cardiovascular health. Journal of the American Dietetic Association, 103, 215-223. [PubMed]

Udedi S.C., Ani O.N., Anajekwu B.N., et al. (2014). Nutritional composition and antioxidant activity of African Walnut, Tetracarpidium conophorum. The Journal of Applied Biochemistry, Photon 107 (2014), 170-180

Udeonyia O.A., Ugese F.D., Aba S.C. and Baiyeri K. P. (2013). Physical properties of seeds of African Walnut (Plukenetia conophorum Muell Arg.) from South-eastern Nigeria, and the effect of boiling on the proximate qualities. Agro-Science, 12 (3), 43-48

Udeonyia O.A., Baiyeri K.P., Ugese F.D. and Aba S.C. (2014). Amino acid profile of seeds of African walnut (Plukenetia conophorum Muell Arg.) from South-eastern Nigeria. Agro-Science, 13 (2), 17-23

Yan W. and Kang M.S. (2003). GGE biplot analysis: a graphical tool for breeders, geneticists and agronomist. CRC Press, Boca, Raton FL 